\title{
PENGEMBANGAN LEMBAR KEGIATAN PESERTA DIDIK (LKPD) BERMUATAN PENDIDIKAN KARAKTER DENGAN MODEL PEMBELAJARAN GUIDED INQUIRY PADA MATERI BAKTERI BAGI SISWA KELAS X SEKOLAH MENENGAH ATAS
}

\section{THE DEVELOPMENT OF LEARNER ACTIVITY SHEET- CHARGED CHARACTER EDUCATION WITH A LEARNING MODEL OF GUIDED INQUIRY ON MATERIAL OF BACTERIA FOR STUDENTS OF CLASS X HIGH SCHOOL}

\author{
Ratna Dewi ${ }^{1)}$, Retni S. Budiarti ${ }^{2}$, Mia Aina ${ }^{3)}$ \\ E-mail:dewiiratna847@gmail.com \\ Staf Pengajar Prodi Pendidikan Biologi FKIP Unja
}

\begin{abstract}
Abstrak. Jenis penelitian ini adalah penelitian pengembangan. Model pengembangan yang digunakan adalah model pengembangan 4D (Define, Design, Develop, Disseminate). Subjek penelitiannya adalah siswa kelas X MIA SMA 2 Kota Jambi. Data hasil validasi ahli dan tanggapan siswa serta guru mata pelajaran biologi sebagai pengguna akan dianalisis secara kualitatif dan kuantitatif, dimana data diperoleh dari angket. Proses validasi telah dilakukan baik oleh validasi ahli materi maupun validasi ahli media. Hasil akhir untuk validasi ahli materi memperoleh persentase 70,4\% termasuk dalam kategori "baik", sedangkan untuk hasil akhir untuk validasi ahli media memperoleh persentase $71 \%$ termasuk dalam kategori "baik". Kemudian hasil yang diperoleh untuk persepsi guru mata pelajaran biologi memperoleh skor $86 \%$ termasuk dalam kategori "sangat baik" dan untuk ujicoba kelompok kecil memperoleh persentase $90 \%$ termasuk kategori "sangat baik". Berdasarkan hasil yang diperoleh baik dari validasi tim ahli, persepsi guru dan respon siswa, maka LKPD bermuatan pendidikan karakter dianggap layak dari segi kualitas materi dan media. Dengan demikian, LKPD bermuatan pendidikan karakter yang telah dikembangkan dapat digunakan sebagai media pembelajaran di SMA Negeri 2 Kota Jambi kelas X pada materi Bakteri.
\end{abstract}

\begin{abstract}
This type of research is research development. Development model used is a 4D model (define, design, develop, disseminate). His research subject is students of class $\mathrm{X}$ SMAN 2 Jambi city. Data validation results responses experts and students as well as teachers of biology subjects as users will be analyzed qualitatively and quantitatively, where the data is retrieved from the now. The validation process has been done either by expert validation the validation material or media expert. The end result for the validation material experts acquire percentage 70,4\% are included in the category of "good", while for the final result to validate media experts acquire a percentage of $71 \%$ is included in the category of "good". The the result obtained for the perception of biological subject teachers earn a score Of $86 \%$ is included in the category "very good" and to test small groups earn a percentage of $90 \%$ included the category "very good". Based on the result obtained from both the validation team of experts, the perception of teacher and student response, then the learner activity sheet-charged character education is considered feasible interms of the quality of the materials and media. A learner activity sheet-charged character education that have been developed can be used as a medium of learning in SMAN 2 Jambi City class X on the material the bacteria
\end{abstract}

Kata Kunci : LKPD, Pendidikan Karakter, Model Pembelajaran Guided Inquiry, Bakteri. 
PENDAHULUAN

Pendidikan di Indonesia diatur dalam Undang-Undang Nomor 20 Tahun 2003 tentang Sistem Pendidikan Nasional mempunyai visi terwujudnya sistem pendidikan sebagai pranata sosial yang kuat dan berwibawa untuk memberdayakan semua warga Negara Indonesia berkembang menjadi manusia yang berkualitas sehingga mampu dan proaktif menjawab tantangan zaman yang selalu berubah.

Diberlakukannya pergantian KTSP menjadi Kurikulum 2013 dianggap dapat memperbaiki sistem pendidikan di Indonesia. Perubahan yang terdapat pada Kurikulum 2013 salah satunya adalah penggabungan mata pelajaran. Selain itu pemerintah juga berencana untuk menambah jam pelajaran agar pembelajaran lebih mengedepankan karakter siswa.

Menurut Suyitno (2012:2), pendidikan karakter di dalam Kurikulum 2013 sangat efektif diterapkan pada jalur pendidikan formal atau sekolah. Pendidikan yang berbasis karakter adalah pendidikan yang menerapkan prinsip-prinsip dan metodologi kearah pembentukan karakter peserta didik melalui kurikulum terintegrasi yang dikembangkan di sekolah. Sebagai agen perubahan, pendidik diharapkan mampu menanamkan ciri-ciri, sifat dan watak serta jiwa mandiri, tanggung jawab dan cakap dalam kehidupan kepada peserta didik. Nilai-nilai yang ditumbuh kembangkan dalam diri peserta didik berupa nilai-nilai dasar yang disepakati secara nasional. Nilai-nilai yang dimaksudkan diantaranya adalah kejujuran, dapat dipercaya, kebersamaan, toleransi, tanggung jawab dan peduli kepada orang lain.

Pendidikan karakter pada usia remaja Sekolah Menengah Atas (SMA) bertujuan untuk pengembangan, oleh karena itu tugas pendidik adalah mengkondisikan lingkungan belajar yang baik untuk mengembangkan karakter siswa. Tujuan pembelajaran biologi di SMA merupakan tujuan terintegrasi pada tujuan ilmu pengetahuan alam (IPA). Dalam IPA, salah satu metode pembelajaran yang dapat membentuk karakter siswa adalah dengan menggunakan model guided inquiry atau inkuiri terbimbing (Suyitno, 2012:4).

Model pembelajaran Guided Inquiry akan membantu mempengaruhi sikap siswa, keputusan yang diambil siswa dan cara-cara memecahkan masalah yang dihadapi siswa, sehingga akan sangat baik apabila diterapkan dalam membantu menumbuhkan nilai karakter siswa. Dalam Guided Inquiry pengetahuan dan keterampilan yang diperoleh siswa diharapkan bukan hanya dari hasil mengingat fakta-fakta, melainkan juga dari menemukan sendiri. Dalam proses inkuiri terbimbing, siswa tidak hanya berperan sebagai penerima materi pelajaran dari guru, melainkan mereka berperan 
untuk menemukan sendiri inti dari materi pelajaran tersebut. Selain itu siswa juga diharapkan dapat menerapkan tujuh nilai karakter dalam pembelajaran biologi, yaitu: (1) menanamkan rasa cinta kepada Tuhan Yang Maha Esa dan Ciptaannya, (2) rasa ingin tahu, cinta ilmu dan hidup sehat, (3) peduli sosial dan lingkungan, (4) berpikir logis, kritis, kreatif dan inovatif, (5) pengembangan sikap ilmiah, (6) disiplin, bertanggung jawab, jujur serta (7) santun, menghargai orang dan keberagaman. (Sanjaya, 2010:208).

Selain itu faktor lain yang perlu dihadapi guna perkembangan pendidikan karakter dalam bidang pendidikan adalah: (1) belum terintegrasinya nilai-nilai karakter didalam perangkat pembelajaran, baik perencanaan pembuatan silabus, RPP, bahan ajar, LKS dimana dalam penggunaan kurikulum 2013 penyebutan LKS mengalami perubahan menjadi LKPD (Lembar Kegiatan Peserta Didik) seiring berkembangnya paradigma pendidikan terhadap peserta didik dan guru, serta sistem penilaian optimal, (2) selama ini guru lebih banyak memanfaatkan bahan ajar yang dikembangkan penerbit dalam bentuk bahan ajar atau buku paket, dan LKPD yang digunakan tidak sesuai dengan kemampuan siswa, (3) belum adanya buku siswa pada mata pelajaran biologi dan LKPD yang mengintegrasikan nilai-nilai pendidikan karakter, (4) proses pembelajaranyang masih berpusat pada guru dan didominasi dengan menggunakan metode ceramah atau tanya jawab, dan (5) proses pembelajaran yang hanya berorientasi pada materi pelajaran.

Berkaitan dengan surat edaran Menteri Pendidikan dan Kebudayaan, dimana terdapat beberapa Sekolah Menengah Atas (SMA) di Kota Jambi yang masih memakai Kurikulum 2013, diantaranya adalah SMA Negeri 1, SMA Negeri 2, SMA Negeri 3, SMA Negeri 4, SMA Negeri 5, SMA Negeri 10 dan SMA Negeri 11. Dari beberapa sekolah tersebut, penulis melakukan observasi ke tiga sekolah yaitu SMA Negeri 2, SMA Negeri 4 dan SMANegeri 5.

Hasil wawancara yang diperoleh dari masing-masing sekolah yaitu: (1) Hasil wawancara di SMA Negeri 2 diketahui bahwa sekolah ini menggunakan Kurikulum 2013, guru bidang studi biologi menjelaskan walau menggunakan Kurikulum 2013 tetapi proses pembelajaran belum sepenuhnya sesuai dengan isi dari Kurikulum 2013 dikarenakan masih kurangnya bahan ajar, sehingga proses pembelajaran masih berpusat pada guru, dan juga belum diterapkannya pendidikan berbasis karakter. Hal ini juga menyebabkan siswa menjadi cenderung bosan dan jenuh selama proses pembelajaran. Di SMA Negeri 2 terdapat Laboratorium IPA dan mikroskop dapat 
digunakan untuk proses pengamatan, sehingga di sekolah ini dapat dilakukan praktikum yang berkaitan dengan pengamatan. (2) Hasil wawancara di SMA Negeri 4 Kota Jambi, penulis memperoleh data dimana siswa merasa jenuh dan bosan saat suasana proses pembelajaran, hal ini dikarenakan guru hanya menggunakan PPT sebagai sumber belajar, selain itu tidak adanya buku ajar juga membuat proses pembelajaran hanya berpusat pada guru (teacher center) dimana hal ini tidak sesuai dengan penerapan Kurikulum 2013, tak hanya itu di sekolah ini pun belum diterapkannya pendidikan berbasis karakter. Dan (3) hasil wawancara di SMA Negeri 5 Kota Jambi, diperoleh data bahwa sekolah ini juga masih menggunakan Kurikulum 2013, untuk LKPD (Lembar Kegiatan Peserta Didik) biasanya guru hanya membuat LKS sederhana dan tidak terpatok dengan Kurikulum 2013.

Berdasarkan hasil wawancara selama observasi, guru mengatakan bahwa di sekolah-sekolah baik SMA Negeri 2, SMA Negeri 4 dan SMA Negeri 5 Kota Jambi kekurangan bahan ajar, dimana salah satu bahan ajar yang dapat membantu proses pembelajaran adalah Lembar Kegiatan Peserta Didik. Penelitian ini, diharapkan dapat membantu mempermudah guru dalam menerapkan nilai-nilai karakter kepada siswa. Adanya LKPD juga dapat digunakan sebagai salah satu bahan ajar bagi siswa dalam melaksanakan proses pembelajaran secaratepat, terarah, objektif dan siswa dapat mengetahui, mempelajari dan menerapkan nilai-nilai karakter dalam kehidupannya.

Tujuan dari penelitian ini adalah mengetahui dan memahami prosedur desain LKPD, mengembangkan LKPD, mengetahui kelayakan LKPD dan mengetahui respon/tanggapan guru dan siswa terhadap LKPD bermuatan pendidikan karakter dengan model pembelajaran guided inquiry pada materi bakteri bagi siswa kelas X SMA.

\section{METODE}

Penelitian ini merupakan penelitian pengembangan. Menurut Borg \& Gall (1983) dalam Setyosari (2012 : 215) "suatu proses yang dipakai untuk mengembangkan dan memvalidasi produk pendidikan yang diikuti suatu langkah-langkah secara siklus. Langkah-langkah penelitian pengembangan terdiri atas kajian tentang temuan penelitian produk yang akan dikembangkan, pengembangan produk berdasarkan temuan, melakukan ujicoba, dan melakukan revisi hasil ujicoba". Model pengembangan yang digunakan penulis dalam penelitian ini adalah model pengembangan 4D. 


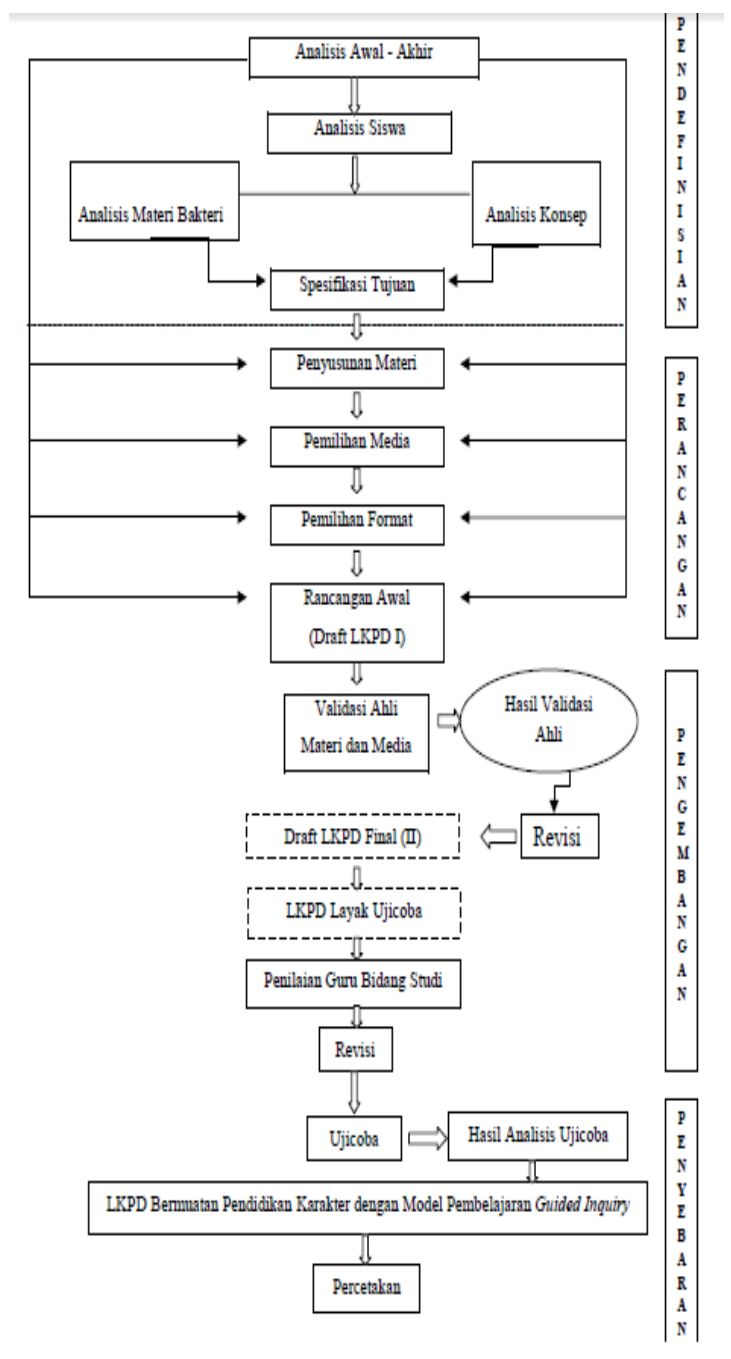

Model pengembangan 4D yang dikemukakan oleh Thiagarajan, et al (Astuti, dkk, 2013 : 90), terdiri dari 4 tahap yaitu tahap pendefinisian (Define), tahap perencanaan (Design), tahap pengembangan (Develop) dan tahap penyebaran (Disseminate). Model pengembangan 4D merupakan model pengembangan media pembelajaran interaktif yang meneliti tentang suatu produk pembelajaran dengan tujuan untuk mengembangkan suatu produk atau program inovatif. Model ini disusun secara terprogram dengan urutan-urutan kegiatan yang sistematis dalam upaya pemecahan masalah belajar yang berkaitan dengan media pembelajaran yang sesuai ngan kebutuhan dan karakteristik siswa.

\section{ANALISIS DATA}

1. Analisis data kualitatif

Seluruh penilaian, saran, dan masukan dari tim validasi ahli selanjutnya dianalisis secara kualitatif. Hasil berupa saran dan masukan yang telah diperoleh dari tim ahli dijelaskan dalam bentuk deskriptif. Data ini digunakan untuk memperbaiki produk yang dihasilkan.

\section{Analisis data kuantitatif}

Data kuantitatif yang diperoleh dari angket tertutup dianalisis dengan perhitungan skor yang diperoleh dari skala Likert. Uji ini dilakukan untuk mengetahui nilai kevalidan yang digunakan dan untuk mendapatkan ukuran kesesuaian dari produk yang dikembangkan.

Rentang skor untuk kategori penilaian yaitu 1-5. Pada setiap angket terdapat indikator penilaian yang memuat beberapa pertanyaan. Pada indikator penilaian angket validasi materi terdapat 25 item pernyataan, angket validasi media terdapat 20 item pernyataan, angket persepsi guru terdapat 10 item pernyataan dan angket tanggapan siswa terdapat 10 item pernyataan. Data kuantitatif yang telah diperoleh kemudian dianalisis dengan cara mentabulasikan hasil angket, dicari rentang 
nilai, dan konveksi nilainya dalam bentuk persentase. Perhitungan rentang nilai digunakan rumus:

\section{Rentang nilai:}

$\frac{\text { Skor Tertinggi }- \text { Skor Terendah }}{\text { KategoriPenilaian }}$

\section{Konveksi nilai :}

$\frac{\text { Skor Terting gi-Skor Terendah }}{\text { KategoriPenilaian }} \times 100 \%$

\section{HASIL DAN PEMBAHASAN}

Berdasarkan pengembangan media pembelajaran berupa Lembar Kegiatan Peserta Didik (LKPD) Bermuatan Pendidikan Karakteryang telah melalui serangkaian tahapan sesuai dengan model pengembangan 4D, maka diperoleh hasil berupa penilaian validator media terhadap desain media, penilaian validator materi terhadap isi media pembelajaran Lembar Kegiatan Peserta Didik (LKPD) Bermuatan Pendidikan Karakter yang dikembangkan, persepsi guru mata pelajaran biologi, persepsi siswa sebagai subjek ujicoba kelompok kecil terhadap penggunaan media dan produk akhir yang dikembangkan

Berikut ini adalah hasil penelitian pada tahap validasi dan ujicoba produk:

\section{Hasil validasi oleh tim ahli}

(a) Hasil validasi oleh validator materi

Media pembelajaran berupa Lembar Kegiatan Peserta Didik (LKPD) Bermuatan Pendidikan Karakter yang telah selesai dirancang selanjutnya divalidasi oleh validator. Proses validasi ini dilakukan sebanyak tiga kali. Dari hasil validasi tersebut diperoleh saran dan perbaikan terhadap isi materi LKPD bermuatan pendidikan karakter yang telah dirancang.

Berikut gambaran Gambar pada hasil validasi ahli instrumen pada validasi pertama, kedua, dan ketiga :

Hasil Validasi Ahli Materi

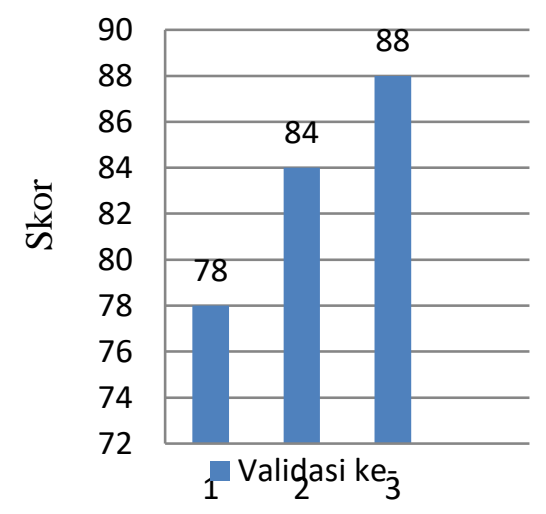

Gambar 1. Hasil Validasi oleh Validator Materi

Berdasarkan hasil validasi pada Gambar 2, dapat diketahui bahwa pada validasi pertama diperoleh skor 78 dengan persentase $62,4 \%$ dan termasuk dalam kriteria “Sedang”.Oleh karena itu, produk harus direvisi pada validasi kedua dan belum layak untuk diujicobakan.

Pada validasi pertama ini terdapat komentar dan saran yang diberikan oleh validator materi yang mendukung dalam proses revisi produk. Perbaikan yang perlu dilakukan diantaranya, penambahan materi terutama tentang gambar struktur sel bakteri, bentuk sel dan cara reproduksinya. 
Proses validasi kedua mendapatkan skor 84 dengan perolehan persentase sebesar $67,2 \%$ termasuk kategori "Baik", dan berdasarkan angket validator ahli materi, LKPD bermuatan pendidikan karakter masih belum dapat diujicobakan ke lapangan karena masih harus ditambahkannya lagi isi materi terutama tentang konjugasi, transduksi dan transformasi pada bakteri, sehingga memerlukan sedikit revisi lagi pada validasi ketiga.Sedangkan Proses validasi ketiga mendapatkan skor 88dengan perolehan persentase sebesar 70,4 \% termasuk kategori "Baik". Berdasarkan data validasi pada angket validator ahli materi, LKPD bermuatan pendidikan karakter dengan model pembelajaran guided inquiry sudah dikatakan valid dan layak untuk diujicobakan tanpa revisi.

\section{(b) Hasil validasi oleh validator media}

Media pembelajaran berupa Lembar Kegiatan Peserta Didik (LKPD) Bermuatan Pendidikan Karakter yang telah divalidasi oleh ahli materi selanjutnya divalidasi oleh ahli media. Proses validasi ini dilakukan sebanyak tiga kali. Dari hasil validasi tersebut diperoleh saran dan perbaikan terhadap media LKPD bermuatan pendidikan karakter yang telah dirancang.

Berikut gambaran Gambar pada hasil validasi ahli instrumen pada validasi pertama, kedua, dan ketiga :

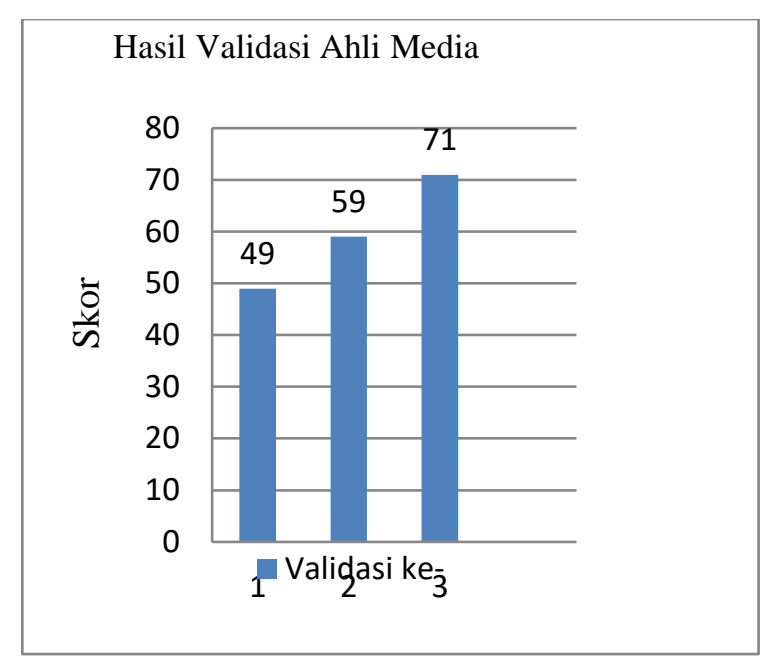

Gambar 2. Hasil Validasi oleh Validator Media

Berdasarkan hasil validasi pada Gambar 3, dapat diketahui bahwa pada validasi pertama diperoleh skor 49 dengan persentase $49 \%$ dan termasuk dalam kriteria "Tidak baik".Oleh karena itu, produk harus direvisi pada validasi kedua dan belum layak untuk diujicobakan.

Pada validasi pertama ini terdapat komentar dan saran yang diberikan oleh validator ahli media yang mendukung dalam proses revisi produk. Perbaikan yang perlu dilakukan diantaranya, perbaiki ukuran font tulisan, perbaiki cover, layout, tulisan penulis dan logo universitas, perbaiki gambar background, tambahkan ilustrasi atau animasi yang relevan dengan teks, perjelas keterangan gambar dan sesuaikan warna dengan objek yang dibahas.

Proses validasi kedua mendapatkan skor 59 dengan perolehan persentase sebesar 59\% termasuk kategori "Sedang", dan berdasarkan angket validator ahli 
media, LKPD bermuatan pendidikan karaktermasih belum dapat diujicobakan ke lapangan karena masih harus diperbaiki lagi. Sedangkan Proses validasi ketiga mendapatkan skor 71 dengan perolehan persentase sebesar $71 \%$ termasuk kategori "Baik". Berdasarkan data validasi pada angket validator ahli media, LKPD bermuatan pendidikan karakter dengan model pembelajaran guided inquiry sudah dikatakan valid dan layak untuk diujicobakan tanpa revisi.

\section{(c) Persepsi guru mata pelajaran biologi}

Persepsi terhadap produk tidak hanya dilakukan kepada siswa, tetapi juga dilakukan kepada guru mata pelajaran biologi. Tujuannya adalah mengetahui penilaian guru terhadap produk. Hasil evaluasi dan persepsi guru menunjukkan bahwa penerapan LKPD yang dikembangkan dapat membantu guru menerapkan nilai-nilai karakter serta membantu siswa dalam proses pembelajaran.

Berdasarkan hasil angket persepsi guru, dapat diketahui bahwa hasil persepsi guru memperoleh skor 43 dengan perolehan hasil persentase sebesar $86 \%$ termasuk dalam kategori "Sangat Baik". Hasil yang ditunjukkan menyatakan pengembangan LKPD bermuatan pendidikan karakter dengan model pembelajaran guided inquiry sangat membantu guru dalam menerapkan nilai-nilai karakter siswa dan membantu dalam proses pembelajaran sebagai bahan ajar.

\section{(d) Hasil ujicoba kelompok kecil}

Subjek yang menjadi responden adalah siswa SMA Negeri 2 Kota Jambi yang berjumlah 12 siswa. Ujicoba produk ini dilakukan pada semester genap, sedangkan materi yang digunakan adalah materi semester ganjil. Ujicoba dilakukan dengan cara simulasi menyerupai keadaan yang sebenarnya pada saat melaksanakan kegiatan pembelajaran. Guru dan siswa meluangkan waktunya 2 jam pelajaran untuk melaksanakan proses ujicoba. Ujicoba produk ini sendiri bertujuan untuk mengetahui respon/tanggapan siswa terhadap LKPD bermuatan pendidikan karakter yang dikembangkan. Berikut gambaran pada hasil ujicoba kelompok kecil:

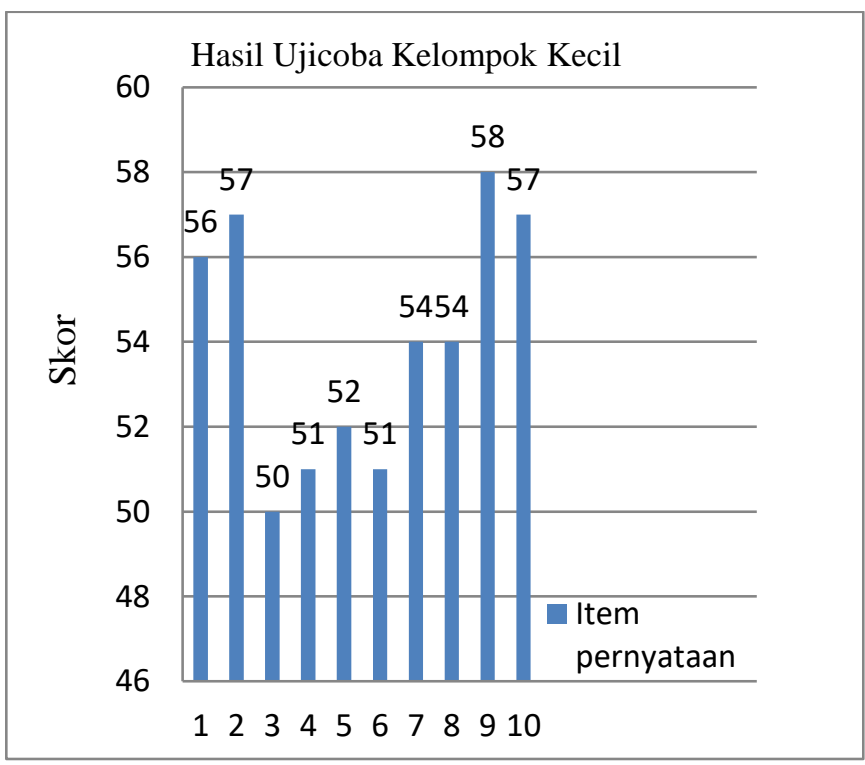

Gambar 4. Hasil Ujicoba Kelompok Kecil

Berdasarkan hasil ujicoba kelompok kecil 12 orang siswa dari 10 item pernyataan pada Gambar 4,dapat diketahui bahwa pada pernyataan ke-9 yang menyatakan "Pembelajaran materi bakteri dalam LKPD ini dapat menambah wawasan" memperoleh skor tertinggi sebesar 58 dengan kategori "Sangat Baik". Sedangkan perolehan yang terendah 
memperoleh skor 50 pada pernyataan ke-3 yang menyatakan "Materi yang disampaikan dalam LKPD ini mudah dipahami" dengan kategori "Sangat Baik". Hasil keseluruhan ujicoba kelompok kecil memperoleh skor 540 dengan perolehan hasil persentase sebesar $\quad 90 \%$ termasuk dalam kategori " Sangat Baik ". Hasil yang ditunjukkan menyatakan bahwa LKPD bermuatan pendidikan karakter dengan model pembelajaran guided inquiry sangat membantu siswa dalam proses pembelajaran serta membantu siswa memahami, mempelajari dan menerapkan nilai-nilai karakter dalam kehidupan.

\section{KESIMPULAN}

Berdasarkan hasil penelitian pengembangan dan pembahasan terkait pengembangan LKPD bermuatan pendidikan karakter dengan model pembelajaran guided inquiry yang dikembangkan,terdapat beberapa hal yang dapat dikaji yaitu:

1. Penulis mengembangkan media pembelajaran Lembar Kegiatan Peserta Didik (LKPD) Bermuatan Pendidikan Karakter ini melalui beberapa tahapan yaitu: menganalisa permasalahan di sekolah, melakukan proses pengumpulan materi yang disajikan di dalam media pembelajaran LKPD bermuatan pendidikan karakter, mendesain media, pencetakan, melakukan validasi desain dan materi pembelajaran media kepada tim ahli, merevisi produk berdasarkan hasil validasi dan saran dari tim ahli, ujicoba kelompok kecil dan persepsi guru mata pelajaran biologi.

2. Media pembelajaran Lembar Kegiatan Peserta Didik (LKPD) Bermuatan Pendidikan Karakter yang dikembangkan terdiri atas beberapa komponen, yakni cover depan LKPD, struktur LKPD dan cover belakang LKPD.

3. (a) Validasi materi pembelajaran Lembar Kegiatan Peserta Didik (LKPD) Bermuatan Pendidikan Karakter dilakukan oleh Ibu Dra. Hj. Harlis, M.Si. Pada proses validasi terjadi beberapa kekurangan sehingga validasi dilakukan 3 kali. Dari segi materi pembelajaran, validasi pertama LKPD memperoleh skor tanggapan 78 dengan persentase $62,4 \%$ termasuk dalam kategori "Sedang". Validasi kedua LKPD memperolehskor 84 dengan persentase $67 \%$ dan termasuk dalam kategori "Baik". Dan validasi ketiga LKPD memperoleh skor 88 dengan persentase $70 \%$ dan termasuk dalam kategori“Baik".

(b) Validasi Media Lembar Kegiatan Peserta Didik (LKPD) Bermuatan Pendidikan Karakter dilakukan oleh Ibu Dr. Upik Yelianti, M.S. Pada proses validasi terjadi beberapa kekurangan sehingga validasi dilakukan 3 kali. Dari segi media, validasi pertama LKPD memperoleh skor tanggapan 49 dengan persentase $49 \%$ dan termasuk dalam kategori "Sedang". Validasi kedua LKPD memperoleh skor 59 dengan persentase $59 \%$ dan termasuk dalam kategori "Sedang". Dan pada validasi ketigaLKPD memperoleh skor 71 dengan persentase $71 \%$ dan termasuk dalam kategori "Baik".

4. Hasil ujicoba produk dari siswa SMA Negeri 2 Kota Jambi dilakukan pada kelompok kecil yang terdiri dari 12 orang siswa, dan tanggapan persepsi satu orang guru mata pelajaran biologi. Skor yang diperoleh pada subjek ujicoba kelompok kecil adalah 540dengan persentase $90 \%$ dan termasuk dalam kategori "Sangat Baik". Sedangkan 
untuk persepsi guru mendapatkan skor adalah 43 dengan persentase $86 \%$ dan termasuk dalam kategori "Baik". Hasil ujicoba ini menunjukkan penerimaan yang sangat baik dari responden dan guru mata pelajaran biologi.

\section{Saran Pemanfaatan}

Adapun saran pemanfaatan dari LKPD bermuatan pendidikan karakter dengan model pembelajaran guided inquiry adalah :

1. Penelitian ini dapat dijadikan sebagai masukan dan acuan dalam mengembangkan produk media yang relevan.

2. Media pembelajaran ini dapat dikembangkan lebih lanjut untuk materi biologi lain.

3. Lembar Kegiatan Peserta Didik (LKPD) Bermuatan Pendidikan Karakter dapat dijadikan sebagai alternatif media pembelajaran biologi di SMA kelas $\mathrm{X}$ IPA pada materi Bakteri atau untuk pembelajaran mandiri siswa.

\section{DAFTAR RUJUKAN}

Alvina dan Agil, 2016, Pengembangan Lembar Kegiatan Peserta Didik (LKPD) Berbasis Scientific Approach Siswa SMA Kelas X Pada Materi Fungi. Jurnal Bioedukasi, Vol 7. No.1 Universitas Muhammadiyah Metro.

Astuti, Y, B. Setiawan. 2013. Pengembangan Lembar Kerja Siswa (LKS) Berbasis Pendekatan Inkuiri Terbimbing Dalam Pembelajaran Kooperatif Pada Materi Kalor.JPII 2 (1) (2013). Halaman 88-92. Diakses tanggal 7 September 2015 dari http://journal.unnes.ac.id/nju/in dex.php/jpii.

Hanif, Ibrohim,Fatchur Rohman. 2016.

Pengembangan

Perangkat

Pembelajaran
Plantae Berbasis Inkuiri

Terbimbing Terintegrasi Nilai Islam

Untuk Meningkatkan Pemahaman

Konsep Siswa SMA, Jurnal Pendidikan, Teori, Penelitian, dan

Pengembangan Volume 1 No.11.

Kemendiknas. 2015. Seputar Keputusan

Mendikbud Soal Penghentian

Kurikulum 2013. Diakses tanggal 8

Desember 2015 dari http://psma.ke mdikbud.go.id/files/SURAT\%20pdf

Sanjaya, W. 2010. Strategi Pembelajaran

Beorientasi Standar Proses

Pendidikan. Jakarta : Kencana.

Setyosari, P. 2010. Metode Penelitian

Pendidikan dan Pengembangan. Jakarta: Kencana.

Siti, Nur K. 2017. Penyusunan LKS Guided Inquiry Untuk Meningkatkan Keterampilan Proses Sains dan Pengetahuan Siswa Materi Animalia, Jurnal Prodi Pendidikan Biologi Vol 6. No.4.

Suyitno, I. 2012. Pengembangan Pendidikan Karakter dan Budaya Bangsa Berwawasan Kearifan Lokal. Jurnal Pendidikan Karakter No: 1 Tahun II 2012. Diakses 4 Desember 2015 dari http://undana.ac.id/. 